\title{
Water quality of the Chhoti Gandak River using principal component analysis, Ganga Plain, India
}

\author{
Vikram Bhardwaj ${ }^{1, *}$, Dhruv Sen Singh ${ }^{1}$ and A K Singh ${ }^{2}$ \\ ${ }^{1}$ Centre of Advanced Study in Geology, University of Lucknow, Lucknow 226 007, India. \\ ${ }^{2}$ Central Institute of Mining and Fuel Research, Barwa Road, Dhanbad 826 001, India. \\ *e-mail: vik_bhardwaj0710@rediffmail.com
}

Chhoti Gandak is a meandering river which originates in the terai area of the Ganga Plain and serves as a lifeline for the people of Deoria district, Uttar Pradesh. It travels a distance of about $250 \mathrm{~km}$ and drains into Ghaghara near Gothani, Siwan district of Bihar. It has been observed that people of this region suffer from water-borne health problems; therefore water samples were collected to analyse its quality along the entire length of Chhoti Gandak River.

The principal components of water quality are controlled by lithology, gentle slope gradient, poor drainage, long residence of water, ion exchange, weathering of minerals, heavy use of fertilizers, and domestic wastes. At some stations water is hard with an excess alkalinity and is not suitable for drinking and irrigation purposes. The variation in the local and regional hydrogeochemical processes distinguished the geogenic sources from the anthropogenic one.

\section{Introduction}

Ganga Plain is one of the most densely populated regions of the world due to its availability of water, fertile soil, and suitable landscape. Density of the river is high in eastern Uttar Pradesh and Bihar. Rivers are considered as a lifeline but are now adversely affecting the population by fluvial hazards (Singh 2007). India is water-stressed and is likely to be water-scarce by 2050 due to the continuous and increasing demand for water (Gupta and Deshpande 2004). Water resources and water quality affect the economic, social, and political development of the society.

It has been observed in the field that people of the Deoria district are suffering from water-borne health problems mainly related to throat, skin, and stomach. The hydrogeochemistry of ground water and anthropogenic control over dolomatization reaction in the alluvial sediments of the Deoria district located within the Chhoti Gandak River Basin have been analysed (Bhardwaj et al
2009). However, no attempt has been made to analyse the water quality and water chemistry of this river. The hydrogeochemical process reveals the zones and quality of water. This process also helps us to understand the changes in water quality due to sediment-water interaction and anthropogenic influence. The impact of land use on the quality of water is an important aspect to develop a suitable policy and legislative or regulatory mechanisms. Lack of such efforts results in the deterioration of water quality which causes health problems and also damages the industrial sector. Therefore, it is essential to evaluate the relationship between chemical variables and to identify local and regional processes which influence quality of water, using principal component analysis for proper planning, water resource management, and sustainable development. Domestic and industrial wastewater constitutes a constant polluting source, whereas surface runoff is a seasonal phenomena mainly controlled by climate within the basin (Singh et al 2004). Weathering of primary

Keywords. Ganga Plain; Chhoti Gandak; water quality; hydrogeochemical; principal component analysis. 


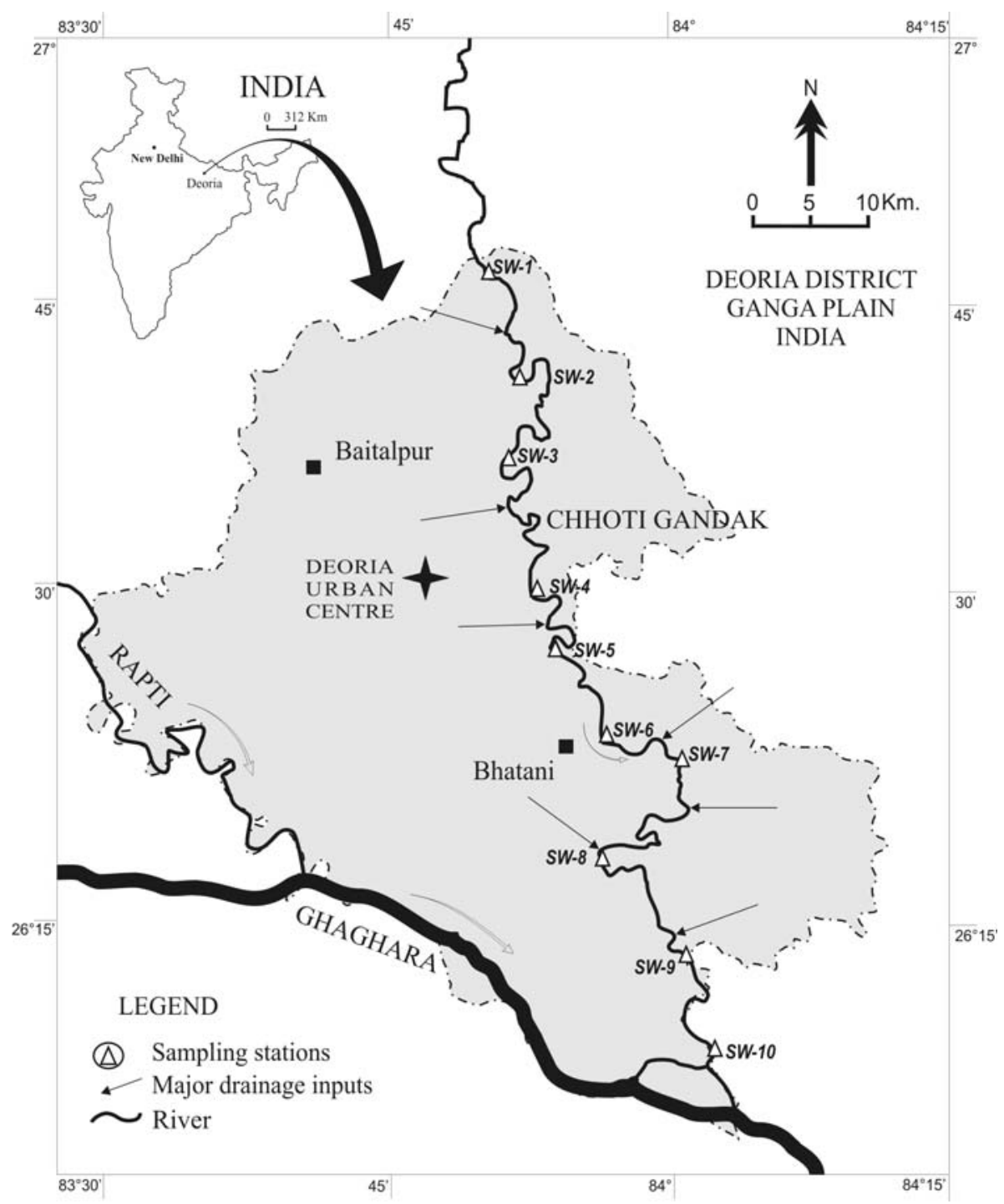

Figure 1. Chhoti Gandak River, Ganga Plain, India.

and secondary minerals contributes to cations and silica in the system (Jacks 1973 and Bartarya 1993).

In the present study, a detailed investigation has been made to identify the hydrogeochemical processes and their relation with water quality, hydrochemical evolution of water system through principal component analysis, and spatial variation in the water quality. Assessment of water quality is important to determine its suitability for consumption in the domestic, agricultural, and industrial sectors.

\section{Study area}

Chhoti Gandak River originates near Dhesopool in Mahrajganj district of Uttar Pradesh and after traveling a distance of about $250 \mathrm{~km}$ towards south, joins the Ghaghara near Gothani in Siwan district of Bihar. Chhoti Gandak River with its tributaries along with Rapti and Ghaghara are the main drainage of the Deoria district. The drainage pattern is subdendritic to dendritic and the streams are perennial to ephemeral in nature. Deoria district is located between $26^{\circ} 06^{\prime}-26^{\circ} 44^{\prime} \mathrm{N}$ latitude and $83^{\circ} 30^{\prime}-84^{\circ} 12^{\prime} \mathrm{E}$ longitude in Uttar Pradesh (figure 1). Basic information of Chhoti Gandak River and Deoria district is given in table 1.

Geologically, the area is made up of Quaternary alluvium of different ages consisting of clay, silt, sand, and gravel mixed in different proportions. The valley and channel width, cliff pattern, point bars and discharge of the river are controlled by climate, the migration and tilting is controlled by tectonics, and river terraces are evolved under the control of both tectonics and climate (Singh et al 2009). Older alluvium (Bhangar) and newer alluvium (Khadar) are the two morphostratigraphic units as described in the classical literature of the 
Table 1. Basic information of Deoria district and Chhoti Gandak River.

\begin{tabular}{ll}
\hline Basic data of Deoria district & \\
\hline Geographical location & Ganga Plain \\
Latitude & $26^{\circ} 06^{\prime} \mathrm{N}-26^{\circ} 44^{\prime} \mathrm{N}$ \\
Longitude & $83^{\circ} 30^{\prime} \mathrm{E}-84^{\circ} 12^{\prime} \mathrm{E}$ \\
Climate & Sub-humid \\
Humidity & $43 \%-84 \%$ \\
Temperature range & $9.0^{\circ} \mathrm{C}-39.2^{\circ} \mathrm{C}$ \\
Average annual rainfall & $1128.11 \mathrm{~mm}$ \\
Average annual & $1323.7 \mathrm{~mm}$ \\
evapotranspiration & \\
Area & $2489.41 \mathrm{~km}{ }^{2}$ \\
Total population $(2001)$ & $27,30,376$ \\
Population density & 1062 \\
Population growth rate & $23.85 \%$ \\
Forested area & $2.61 \mathrm{~km}^{2}$ \\
Salt affected land & $33.66 \mathrm{~km}^{2}$ \\
Cultivable land & $2117.16 \mathrm{~km}{ }^{2}$ \\
Rangeland & $40.28 \mathrm{~km}^{2}$ \\
Flood affected land & $10.75 \mathrm{~km}^{2}$ \\
\hline Basic data of Chhoti Gandak River \\
\hline Slope gradient & $21.00 \mathrm{~cm}^{2} \mathrm{~km}^{2}$ \\
Sinuosity & 2.05 \\
Valley width & $0.1-0.5 \mathrm{~km}$ \\
Channels widths & $25-200 \mathrm{~m}$ \\
Relief (both the banks) & 0.1 to $7.0 \mathrm{~m}$ \\
\hline
\end{tabular}

Ganga Plain (Pascoe 1917). Upland terrace surface, river valley terrace surface, and present day river channel made up of older alluvium and newer alluvium are the main geomorphic units which are depositional in nature (Singh 1996). Two main depositional areas, identified in the Ganga Plain are (a) channel areas and (b) interchannel areas. Sedimentation in the interchannel areas takes place mainly by sheet flow (Kumar et al 1995), and interfluve deposits (Singh et al 1999). Whereas river deposit sediments in the channel areas are in the form of channel-bar deposits (Singh and Singh 2005).

\section{Methodology}

Water samples were collected in two sets from different stations at regular intervals along the entire length of Chhoti Gandak River during summer (June), 2006. The collected samples were stored in acid-cleaned, high-density polyethylene (HDPE) bottles $(1000 \mathrm{ml})$, which were carefully rinsed three times before use. The use of HDPE bottles minimizes container pollution and promotes the sample preservation (Hall 1998). Analyses of water samples were carried out immediately after collection. Samples were stored in a refrigerator at $4{ }^{\circ} \mathrm{C}$ prior to analysis. Temperature, $\mathrm{pH}$, conductivity, total dissolved solids were determined in the field by Cyber Scan 510. Potassium and sodium by Systronics Flame photometer 128, nitrate by Perkin Elmer, UV/VIS spectrometer, Lambda 40. Other parameters were measured using standard water quality procedures (American Public Health Association 1992, 1998). The reproducibility of the analytical procedures was checked by carrying out duplicate analysis. The variation in result was less than $5 \%$ of the mean. Ability to replicate samples was determined by collecting two samples at every station.

Chemical data were analyzed by the principal component analysis, which quantifies relationship between the variables by computing the matrix of correlations for the entire dataset. In the present study results of the first three principal components were selected following Kaiser (1958) to explain the hydro-geochemical processes that control the ion concentrations of water, which account for most of the total variance in the dataset.

\section{Results and discussion}

\subsection{Water quality of the river}

Analysis of the chemical constituents of the Chhoti Gandak River at different stations is shown in tables 2 and 3. The tables indicate that the concentration of $\mathrm{pH}$ ranges from 6.24 to 8.61 and total dissolved solid (TDS), which is a measure of the degree of quality, varies from $60-192.6 \mathrm{mg} / \mathrm{L}$, with a mean of $103.56 \mathrm{mg} / \mathrm{L}$. As per the classification of TDS (Fetter 1990), all the water samples come under fresh type (TDS $<1000 \mathrm{mg} / \mathrm{L}$ ). The total hardness $(\mathrm{TH})$ in the water is in the range of $45-$ $370 \mathrm{mg} / \mathrm{L}$ which indicates that the water of some sampling stations belongs to a very hard category (>300 mg/L; Twort et al 1974). Cation and anion analysis shows that the content of $\mathrm{Ca}^{2+}$ is between 6 and $36 \mathrm{mg} / \mathrm{L} ; \mathrm{Mg}^{2+}$ is between 4.8 and $42 \mathrm{mg} / \mathrm{L}$, $\mathrm{Na}^{+}$is between 12 and $86 \mathrm{mg} / \mathrm{L}, \mathrm{K}^{+}$is between 2.1 and $116 \mathrm{mg} / \mathrm{L} ; \mathrm{HCO}_{3}^{-}$is between 98 and $451 \mathrm{mg} / \mathrm{L} ; \mathrm{Cl}^{-}$is between 3.5 and $121 \mathrm{mg} / \mathrm{L} ; \mathrm{SO}_{4}^{2-}$ is between 88 and $186 \mathrm{mg} / \mathrm{L} ; \mathrm{NO}_{3}^{-}$is between 14 and $38 \mathrm{mg} / \mathrm{L}$; and $\mathrm{F}^{-}$is between 0.4 and $0.59 \mathrm{mg} / \mathrm{L}$, with mean values of $20.6,18.2,35.4,21.2,195.6$, $38.1,134.5,24.5$, and $0.45 \mathrm{mg} / \mathrm{L}$, respectively. Water is characterized by $\mathrm{Na}^{+}>\mathrm{Ca}^{2+}>\mathrm{Mg}^{2+}$ : $\mathrm{HCO}_{3}^{-}>\mathrm{SO}_{4}^{2-}>\mathrm{Cl}^{-}>\mathrm{NO}_{3}^{-}$facies.

The $\mathrm{pH}$ and concentration of $\mathrm{TH}$ and $\mathrm{Ca}^{2+}$ in 40, 80 and $10 \%$ respectively of the water samples are more than the safe permissible limits proposed 


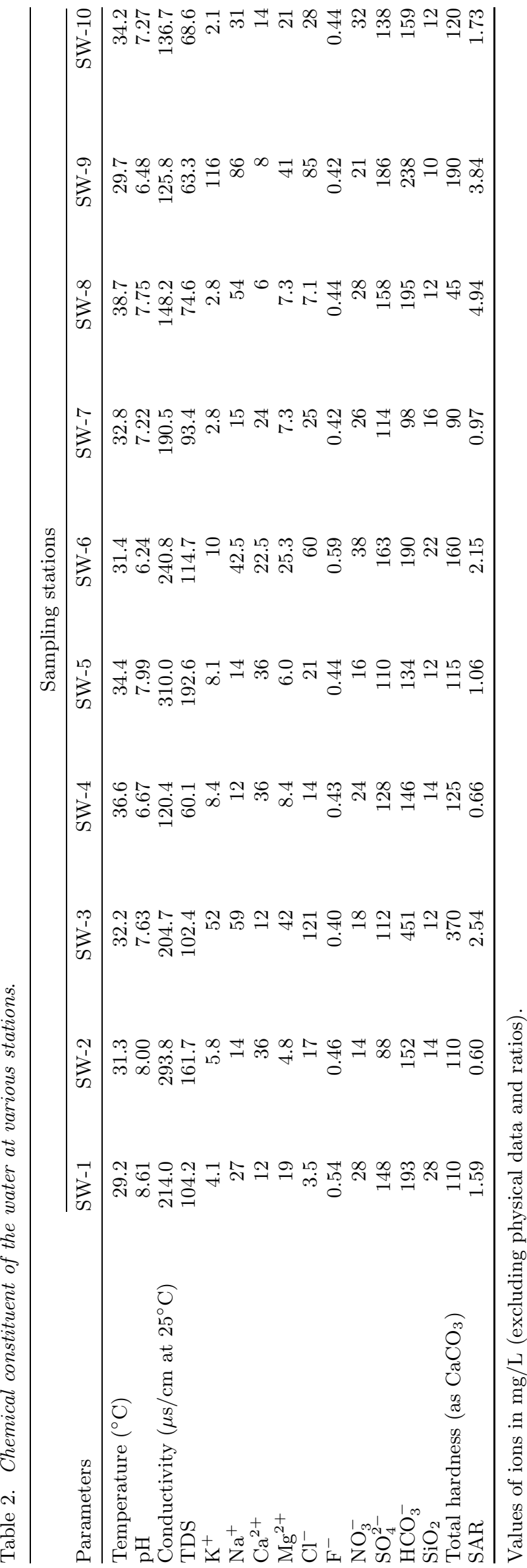

by Indian Standard Institute (1983) and World Health Organization (1984) (7-8.5 for $\mathrm{pH}$, $100 \mathrm{mg} / \mathrm{L}$ for $\mathrm{TH}$ and $30 \mathrm{mg} / \mathrm{L}$ for $\mathrm{Ca}^{2+}$ ) (table 4). So it can have an adverse affect on human health (Holden 1970; Maiti 1982). About $80 \%$ of the total water samples fall in the $\mathrm{C} 1-\mathrm{S} 1$ zone of salinity diagram (figure 2), and $20 \%$ in $\mathrm{C} 1-\mathrm{S} 2$ zones in the EC/SAR diagram (sodium adsorption ratio $=\mathrm{Na}^{+} /\left\{\left[\mathrm{Ca}^{2+}+\mathrm{Mg}^{2+}\right] / 2\right\} 0.5$ ) (figure 2). This comes under the good water quality zone for irrigation (table 4). About $20 \%$ of the total water samples fall in the permissible to doubtful category and $70 \%$ of the samples come under excellent to good category and rest of the samples $(10 \%)$ comes under good to permissible category in the EC $/ \% \mathrm{Na}^{+}$diagram $\left[\right.$per cent $\mathrm{Na}^{+}=\left(\mathrm{Na}^{+}+\mathrm{K}^{+}\right) \times$ $\left.100 /\left(\mathrm{Ca}^{2+}+\mathrm{Mg}^{2+}+\mathrm{Na}^{+}+\mathrm{K}^{+}\right)\right]$(figure 3$)($ table 4$)$.

\subsection{Compositional relations}

Compositional relations in water show that conductivity has a strong correlation with TDS, and moderate correlations with $\mathrm{Ca}^{2+}$ and $\mathrm{pH}$. TDS has correlation with $\mathrm{Ca}^{2+}$ and $\mathrm{pH} . \mathrm{K}^{+}$has strong correlation with $\mathrm{Na}^{+}, \mathrm{Mg}^{2+}$ and moderate correlation with $\mathrm{Cl}^{-}, \mathrm{SO}_{4}^{2-}, \mathrm{HCO}_{3}^{-}$and total hardness. $\mathrm{Na}^{+}$has a good correlation with $\mathrm{Mg}^{2+}, \mathrm{SO}_{4}^{2-}, \mathrm{Cl}^{-}$, $\mathrm{HCO}_{3}^{-}$and total hardness. $\mathrm{Mg}^{2+}$ has high correlation with $\mathrm{Cl}^{-}$, total hardness, $\mathrm{HCO}_{3}^{-}$and moderate correlation with $\mathrm{SO}_{4}^{2-}$ ions. $\mathrm{Cl}^{-}$has a good correlation with $\mathrm{HCO}_{3}^{-}$and $\mathrm{SiO}_{2}$. $\mathrm{NO}_{3}^{-}$has correlation with $\mathrm{SO}_{4}^{2-}$ and $\mathrm{HCO}_{3}^{-}$. Total hardness has strong correlation with $\mathrm{HCO}_{3}^{-}$.

\subsection{Principal component analysis}

The principal component analyses for the water of Chhoti Gandak River are shown in table 5 . It includes loading for the rotated component matrix, eigenvalues for each component, per cent and cumulative per cent of variance explained by each component, and communality indicating the proportion of variance of each variable controlled by the set of components.

It indicates that the first three principal components together account for $77.966 \%$ of the total variance in the dataset, in which the first principal component is $34.139 \%$, second principal component is $25.671 \%$, and the third principal component is $18.156 \%$ of the total variance. The high (0.7-0.98) values of communality for all chemical variables (15) and the eigenvalues of the first three principal components (more than one) can be used to assess the dominant hydrogeochemical processes. The concentrations of $\mathrm{Cl}^{-}, \mathrm{Mg}^{2+}, \mathrm{TH}$, $\mathrm{HCO}_{3}^{-}, \mathrm{K}^{+}$, and $\mathrm{Na}^{+}$show high positive loadings (0.728-0.941) whereas concentrations of $\mathrm{SO}_{4}^{2-}$ have 
Table 3. Descriptive statistics of the analyzed chemical components (at 10 sampling stations).

\begin{tabular}{|c|c|c|c|c|c|}
\hline Parameter & Minimum & Maximum & Mean & $\begin{array}{l}\text { Standard } \\
\text { deviation }\end{array}$ & $\begin{array}{c}\text { Coefficient of } \\
\text { variation }\end{array}$ \\
\hline Temperature & 29.2 & 38.7 & 33.05 & 2.98673 & 8.9206 \\
\hline $\mathrm{pH}$ & 6.24 & 8.61 & 7.386 & 0.75424 & 0.5689 \\
\hline Conductivity & 120.7 & 310 & 198.52 & 67.76903 & 4292.6418 \\
\hline TDS & 60.1 & 192.6 & 103.56 & 43.59916 & 1900.8871 \\
\hline $\mathrm{K}^{+}$ & 2.1 & 116 & 21.21 & 36.46622 & 1329.7854 \\
\hline $\mathrm{Na}^{+}$ & 12 & 86 & 35.45 & 24.68293 & 604.2472 \\
\hline $\mathrm{Ca}^{2+}$ & 6 & 36 & 20.65 & 11.97231 & 143.3361 \\
\hline $\mathrm{Mg}^{2+}$ & 4.8 & 42 & 18.205 & 14.16773 & 200.7247 \\
\hline $\mathrm{Cl}^{-}$ & 3.5 & 121 & 38.16 & 38.44448 & 1477.9782 \\
\hline $\mathrm{F}^{-}$ & 0.4 & 0.59 & 0.458 & 0.05978 & 0.03573 \\
\hline $\mathrm{NO}_{3}^{-}$ & 14 & 38 & 24.5 & 7.47217 & 55.8333 \\
\hline $\mathrm{SO}_{4}^{2-}$ & 88 & 186 & 134.5 & 29.7069 & 882.5000 \\
\hline $\mathrm{HCO}_{3}^{-}$ & 98 & 451 & 195.6 & 97.80161 & 9565.1556 \\
\hline $\mathrm{SiO}_{2}$ & 10 & 28 & 15.2 & 5.59365 & 31.2889 \\
\hline Total hardness & 45 & 370 & 143.5 & 88.35063 & 7805.8333 \\
\hline
\end{tabular}

Table 4. Compliance of river water quality of water samples (\%) to drinking and irrigation standards.

\begin{tabular}{|c|c|c|c|}
\hline \multicolumn{4}{|c|}{ Distribution of water samples } \\
\hline $\begin{array}{l}\text { Chemical } \\
\text { constituents }\end{array}$ & WHO (1984) & ISI (1983) & $\begin{array}{l}\text { Samples }(\%) \\
\text { exceed the safety } \\
\text { limits }\end{array}$ \\
\hline $\mathrm{pH}$ & $7-8.5$ & $7-8.5$ & 40 \\
\hline TDS & 500 & 500 & Within the range \\
\hline $\mathrm{TH}$ & 100 & 300 & 80 \\
\hline $\mathrm{Ca}^{2+}$ & 75 & 75 & Within the range \\
\hline $\mathrm{Mg}^{2+}$ & 30 & 30 & 10 \\
\hline $\mathrm{Na}^{+}$ & 200 & - & Within the range \\
\hline $\mathrm{HCO}_{3}^{-}$ & - & 300 & Within the range \\
\hline $\mathrm{Cl}^{-}$ & 200 & 250 & Within the range \\
\hline $\mathrm{SO}_{4}^{2-}$ & 200 & 150 & Within the range \\
\hline $\mathrm{NO}_{3}^{-}$ & 45 & 45 & Within the range \\
\hline $\mathrm{F}^{-}$ & 1.5 & $0.6-1.2$ & Within the range \\
\hline \multicolumn{4}{|c|}{ Irrigation purpose } \\
\hline Diagram & Zone & Samples (\%) & Water quality type \\
\hline \multirow[t]{2}{*}{ EC versus SAR } & $\mathrm{C} 1-\mathrm{S} 1$ & 80 & Good \\
\hline & $\mathrm{C} 1-\mathrm{S} 2$ & 20 & Good \\
\hline \multirow[t]{3}{*}{$\mathrm{EC}$ versus $\% \mathrm{Na}$} & Permissible to doubtful & 20 & Good \\
\hline & Excellent to good & 70 & Good \\
\hline & Good to permissible & 10 & Good \\
\hline
\end{tabular}

low positive loadings $(0.205)$ for the first principal component. In the second principal component TDS, conductivity, and $\mathrm{Ca}^{2+}$ concentrations have high positive loadings $(0.785-0.890)$ and the concentration of $\mathrm{pH}, \mathrm{TH}, \mathrm{F}^{-}$, and $\mathrm{SiO}_{2}$ shows low positive loading (0.016-0.324). For the third principal component, the concentrations of $\mathrm{F}^{-}$, and $\mathrm{SiO}_{2}$ show high positive loadings (0.904-0.951), the concentrations of $\mathrm{NO}_{3}^{-}$show moderate positive loadings (0.584) and the concentrations of $\mathrm{SO}_{4}^{2-}$, 


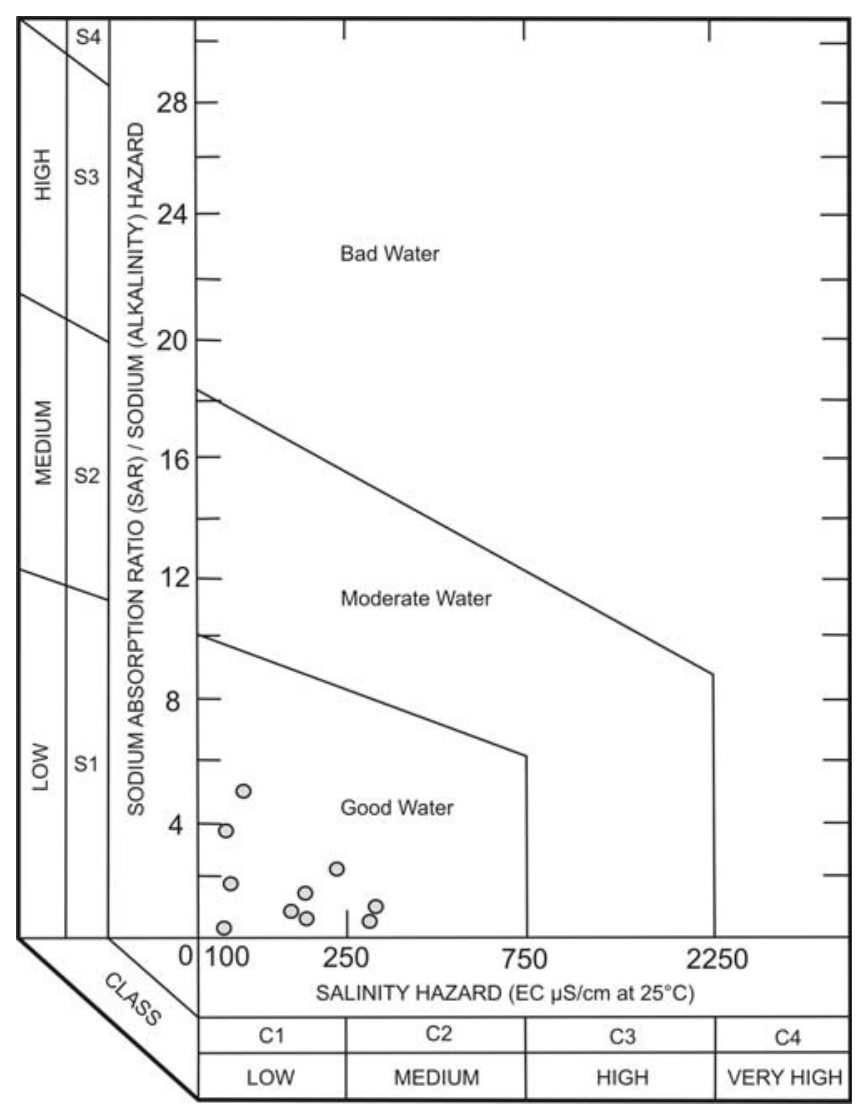

Figure 2. Classification of water for irrigation. Circles denote the chemical data of the water sampling stations.

conductivity, TDS, $\mathrm{Mg}^{2+}$, and $\mathrm{pH}$ show low positive loadings (0.025-0.327).

The high positive loadings of $\mathrm{Cl}^{-}, \mathrm{Mg}^{2+}, \mathrm{TH}$, $\mathrm{HCO}_{3}^{-}, \mathrm{K}^{+}$, and $\mathrm{Na}^{+}$ions on the first principal component suggest that the first principal component is associated with a combination of various hydrogeochemical processes and augment more mineralized water (TDS). For instance, a high positive loading of $\mathrm{Na}^{+}$ion suggests ion exchange on the clay materials. The process of dissolution of $\mathrm{Na}^{+}$and $\mathrm{Cl}^{-}$ions indicates a higher rate of weathering in the area. Low slope gradient causes longer residence time for water and higher water-rock interactions which result in the enrichment of $\mathrm{Na}^{+}$ and $\mathrm{Cl}^{-}$ions, apart from their higher solubility character. The concentration of $\mathrm{HCO}_{3}^{-}$in water is the result of the reaction of soil $\mathrm{CO}_{2}$ with the dissolution of silicate minerals. Generally, mineral dissolution during water-soil and water-rock interactions depends on the amount of $\mathrm{CO}_{2}$, originated from $\mathrm{H}_{2} \mathrm{CO}_{3}$. Thus, mineral saturation in water depends on the amount of $\mathrm{pCO}_{2}, \mathrm{Ca}^{2+}, \mathrm{CO}_{2}$, $\mathrm{HCO}_{3}^{-}$, and $\mathrm{H}_{2} \mathrm{CO}_{3}$. Decrease in $\mathrm{pCO}_{2}$ and $\mathrm{H}_{2} \mathrm{CO}_{3}$ values during out gassing of $\mathrm{CO}_{2}$ results in increase of $\mathrm{HCO}_{3}^{-}$and $\mathrm{pH}$ levels (Ozler 2003). The concentration of $\mathrm{TH}$ and $\mathrm{HCO}_{3}^{-}$suggests that most of the hardness in the water is temporary. The high positive loadings of $\mathrm{K}^{+}$and $\mathrm{Mg}^{2+}$ ions, for the first principal component indicate the weathering of feldspar and ferro-magnesium minerals together with anthropogenic sources (Hem 1991; Zhang et al 1995 and Satyanarayana and Periakali 2003). The higher concentrations of TDS observed on the first principal component is related to $\mathrm{Ca}^{2+}$ and conductivity which is an indication of man-made pollution due to domestic wastes (Chettri and Smith 1995; Fisher and Mullican 1997 and Scheytt 1997). The concentration of $\mathrm{NO}_{3}^{-}$in the water is also anthropogenic (irrigation return flow, fertilizers, and domestic wastes). The combination of $\mathrm{HCO}_{3}^{-}$and $\mathrm{NO}_{3}^{-}$ions is an indication of the hydrogeochemical effect of runoff leakage on the water (Wang and Luo 2001). The association of $\mathrm{F}^{-}$and $\mathrm{SiO}_{2}$ in water is due to ion exchange of $\mathrm{F}^{-}$and $\mathrm{OH}^{-}$ in the clay minerals, low slope gradient, longer residence of water in the aquifer zone, intensive and long-term irrigational practices, and heavy use of fertilizers (Subba Rao and Devadas 2003).

The function of geogenic and anthropogenic activities on the water chemistry can be assessed with the help of scatter diagrams, ionic signatures, and mechanisms controlling the water chemistry diagrams to explain the processes responsible for controlling the water quality. The chemical data of water for half of the sampling stations with respect to $\mathrm{Ca}^{2+}$ and $\mathrm{Mg}^{2+}$ ions (called alkalineearth elements) $/ \mathrm{HCO}_{3}^{-}$in this area (figure $4 \mathrm{~A}$ ) fall below the equiline. This suggests that excess of alkalinity $\left(\mathrm{HCO}_{3}^{-}\right)$in the water is balanced by alkalis $\left(\mathrm{Na}^{+}\right.$plus $\left.\mathrm{K}^{+}\right)$. The plotting of chemical data related to the alkaline-earth elements/total cations (TC) in the water shows that the chemical data lie far below the equiline (figure 4B). This indicates an increasing contribution of the alkalis on TC. Significantly, the decrease in the alkalis corresponds to a simultaneous increase in the $\mathrm{Cl}^{-}$plus $\mathrm{SO}_{4}^{2-}$ ions (figure $4 \mathrm{D}$ ), suggesting a different source for these ions. A plot of $\mathrm{Na}^{+}+\mathrm{K}^{+} / \mathrm{Cl}^{-}$is illustrated in figure $4 \mathrm{E}$. Excess of $\mathrm{Na}^{+}$over $\mathrm{Cl}^{-}$in the water reflects silicate weathering (Stallard and Edmond 1983). The water in the area has a high ratio of $\mathrm{Na}^{+}$plus $\mathrm{K}^{+} / \mathrm{TC}$ (figure 4G) depicting the contribution of cations through silicate weathering and/or soils (Sarin et al 1989). At a majority of sampling stations, $\mathrm{Cl}^{-}$ plus $\mathrm{SO}_{4}^{2-}$ is greater than $\mathrm{HCO}_{3}^{-}$(figure $4 \mathrm{H}$ ). The relative abundance of $\mathrm{Cl}^{-}$plus $\mathrm{SO}_{4}^{2-}$ compared to $\mathrm{HCO}_{3}^{-}$(figure $4 \mathrm{H}$ ) is due to the enriched water particularly in $\mathrm{SO}_{4}^{2-}$. Except one sampling station for which $\mathrm{SO}_{4}^{2-}>\mathrm{Cl}^{-}$(figure $4 \mathrm{~F}$ ).

The ionic signature $\mathrm{Na}^{+}: \mathrm{Ca}^{2+}$, is lower than unit except for three sampling stations (SW-3, SW-8 and SW-9) (table 6) and indicates a 
Table 5. Rotated component matrix of chemical data.

\begin{tabular}{lrrrc}
\hline & \multicolumn{4}{c}{ Principal components } \\
\cline { 2 - 5 } Parameter & $\mathrm{I}$ & $\mathrm{II}$ & $\mathrm{III}$ & Communality \\
\hline $\mathrm{K}^{+}$ & 0.796 & -0.233 & -0.208 & 0.79 \\
$\mathrm{Na}^{+}$ & 0.728 & -0.569 & -0.052 & 0.86 \\
$\mathrm{Mg}^{2+}$ & 0.922 & -0.318 & 0.114 & 0.97 \\
$\mathrm{Cl}^{-}$ & 0.941 & -0.031 & -0.109 & 0.94 \\
$\mathrm{HCO}_{3}^{-}$ & 0.859 & -0.104 & -0.119 & 0.85 \\
Total hardness & 0.901 & 0.128 & -0.109 & 0.84 \\
$\mathrm{TDS}^{-}$ & -0.060 & 0.890 & 0.146 & 0.85 \\
$\mathrm{NO}_{3}^{-}$ & -0.248 & -0.613 & 0.584 & 0.84 \\
$\mathrm{SO}_{4}^{2-}$ & 0.205 & -0.791 & 0.327 & 0.84 \\
$\mathrm{Ca}^{2+}$ & -0.423 & 0.785 & -0.109 & 0.94 \\
$\mathrm{Conductivity}^{2+}$ & -0.017 & 0.875 & 0.301 & 0.89 \\
Temperature & -0.556 & -0.246 & -0.577 & 0.70 \\
$\mathrm{SiO}_{2}$ & -0.164 & 0.016 & 0.904 & 0.87 \\
$\mathrm{~F}^{-}$ & -0.140 & 0.019 & 0.951 & 0.93 \\
$\mathrm{pH}_{\text {Eigenvalues }}$ & -0.175 & 0.324 & 0.025 & 0.98 \\
explained by & 5.995 & 3.345 & 2.575 & \\
component & 34.139 & 25.671 & 18.156 & \\
$\mathrm{Cumulative} \%$ age & & & & \\
of variance & 34.139 & 59.890 & 77.966 & \\
\hline
\end{tabular}

moderate concentration of $\mathrm{Ca}^{2+}$. The moderate concentration of $\mathrm{Ca}^{2+}$ in the water is due to the ion exchange, which indicates an excess of alkalis over alkaline earth elements (figure 4C). The negative values $(-0.006$ to -2.12$)$ of the Index of Base Exchange (IBE), i.e., IBE I $\left(\mathrm{Cl}^{-}-\mathrm{Na}^{+}+\mathrm{K}^{+}: \mathrm{Cl}^{-}\right)$ and IBE II $\left(\mathrm{Cl}^{-}-\mathrm{Na}^{+}+\mathrm{K}^{+}: \mathrm{HCO}_{3}^{-}\right)$further support the enrichment of $\mathrm{Na}^{+}$in the water because of the clay horizons. The excess of $\mathrm{Na}^{+}$over $\mathrm{K}^{+}$ in the water is due to the greater resistance of $\mathrm{K}^{+}$ to the weathering and its absorption on the clay minerals.

Chemical data of water samples point towards a rock-dominance zone, according to the variations in the ratios of $\mathrm{Na}^{+}:\left(\mathrm{Na}^{+}+\mathrm{Ca}^{2+}\right)$ and $\mathrm{Cl}^{-}:\left(\mathrm{Cl}^{-}+\mathrm{HCO}_{3}^{-}\right)$as a function of TDS in the water chemistry diagrams (figure 5). These diagrams assess the functional sources of dissolved ions as precipitation dominance, rock dominance, and evaporation dominance, which control the water chemistry (Gibbs 1970). The climatic conditions (sub-humid) also affect the evaporation and increase the concentrations of ions and thus TDS.

The area has mostly cultivable land with gentle slope gradient $(21 \mathrm{~cm} / \mathrm{km})$ which is in partial equilibrium with the materials of the basins in a sub-humid climate. Chemical data's position within the rock dominance group depends on the

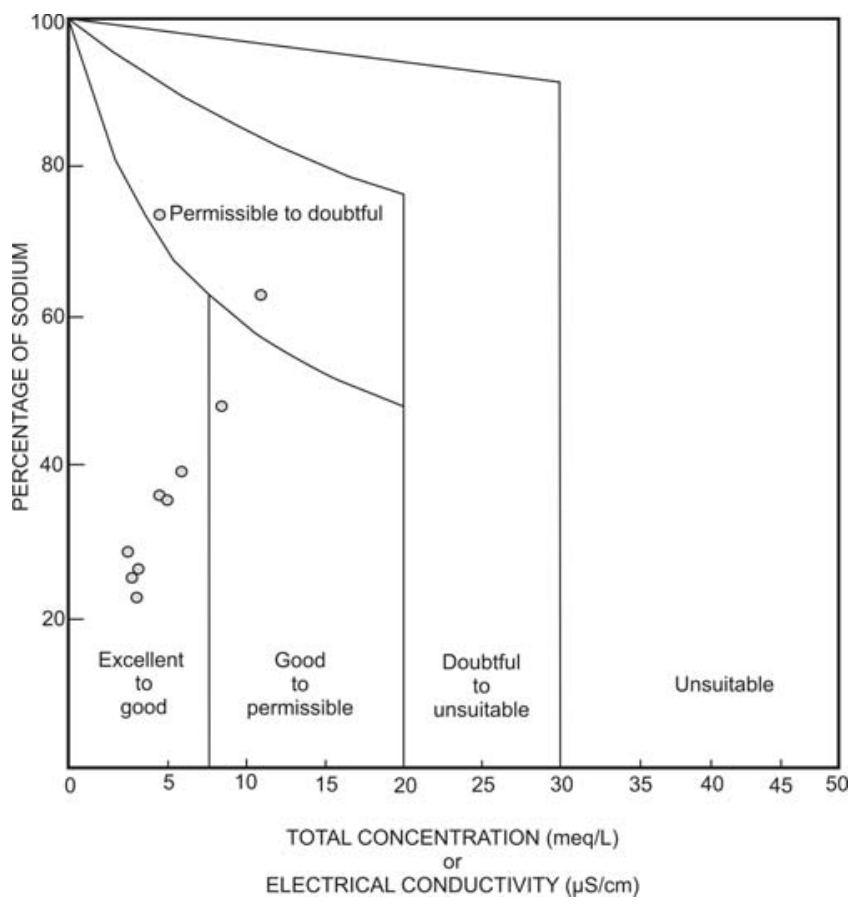

Figure 3. Suitability of water for irrigation. Circles denote the chemical data of the water sampling stations.

relief, climate, and the composition of the material in the basin. It supports the view of scatter diagrams, ionic signatures, and mechanisms controlling the water chemistry diagrams, which explain 

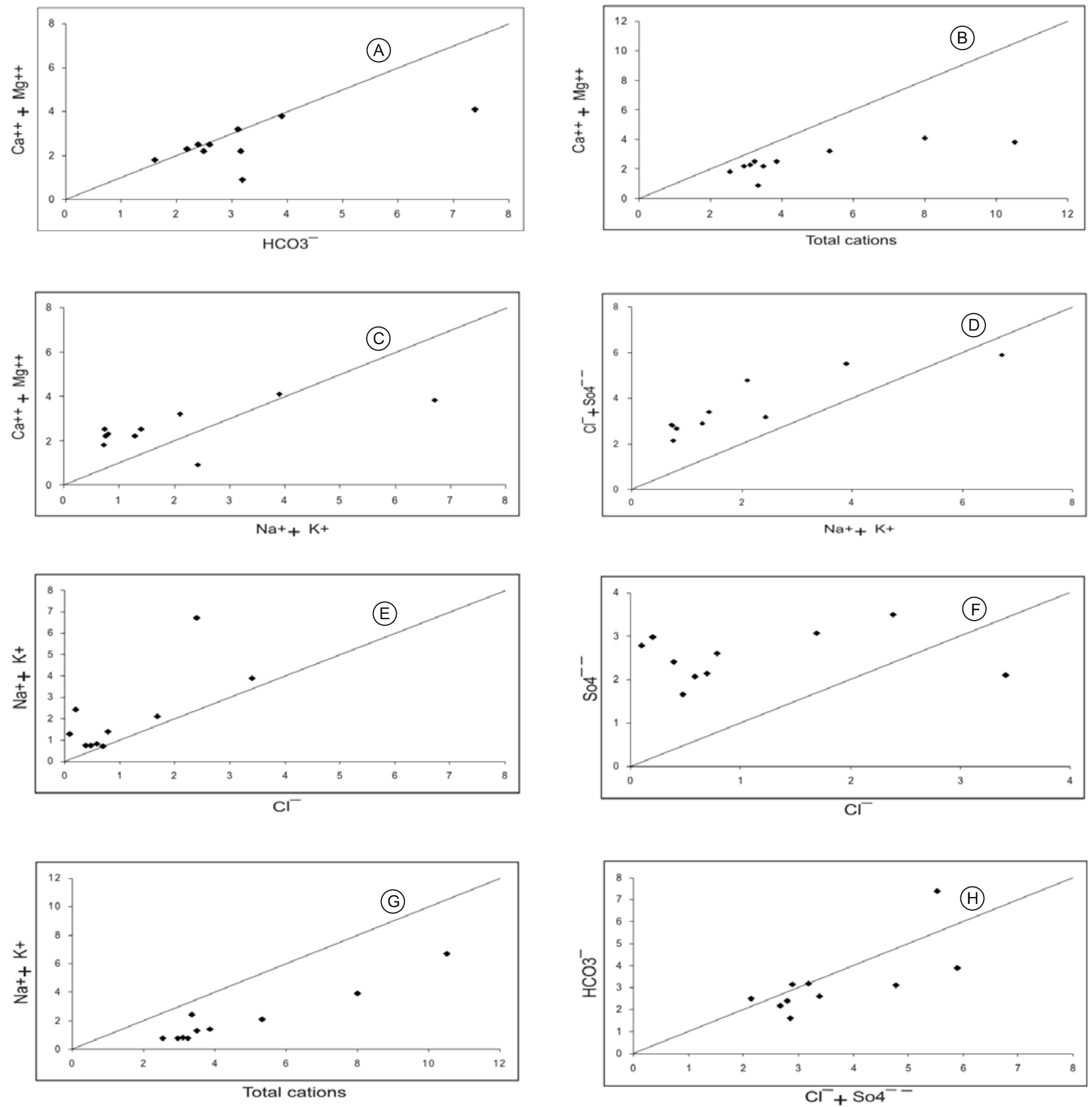

Figure 4. Scatter plots: A to H.

Table 6. Particulars of ionic signatures.

\begin{tabular}{lccccccccrr}
\hline & \multicolumn{1}{c}{ Sampling stations } \\
\cline { 2 - 10 } Signatures & SW-1 & SW-2 & SW-3 & SW-4 & SW-5 & SW-6 & SW-7 & SW-8 & SW-9 & SW-10 \\
\hline $\begin{array}{l}\mathrm{Na}^{+}: \mathrm{Ca}^{2+} \\
(\mathrm{mmol} / \mathrm{L})\end{array}$ & 0.98 & 0.17 & 2.14 & 0.15 & 0.17 & 0.83 & 0.27 & 3.92 & 4.68 & 0.96 \\
$\mathrm{IBE}-1(\mathrm{meq} / \mathrm{L})$ & -0.006 & 0.183 & 1.23 & 0.42 & 0.332 & -0.007 & 0.16 & -1.75 & -0.11 & -0.486 \\
$\mathrm{IBE}-2(\mathrm{meq} / \mathrm{L})$ & -1.046 & -0.067 & 1.02 & -0.04 & -0.09 & -0.77 & 0.1 & -2.12 & -0.59 & -0.536 \\
\hline IBE = index of base exchange; IBE-1 & $\left(\mathrm{Cl}^{-}-\mathrm{Na}^{+}+\mathrm{K}^{+}: \mathrm{Cl}^{-}\right) ; \mathrm{IBE}-2=\left(\mathrm{Cl}^{-}-\mathrm{Na}^{+}+\mathrm{K}^{+}: \mathrm{HCO}_{3}^{-}\right)$.
\end{tabular}



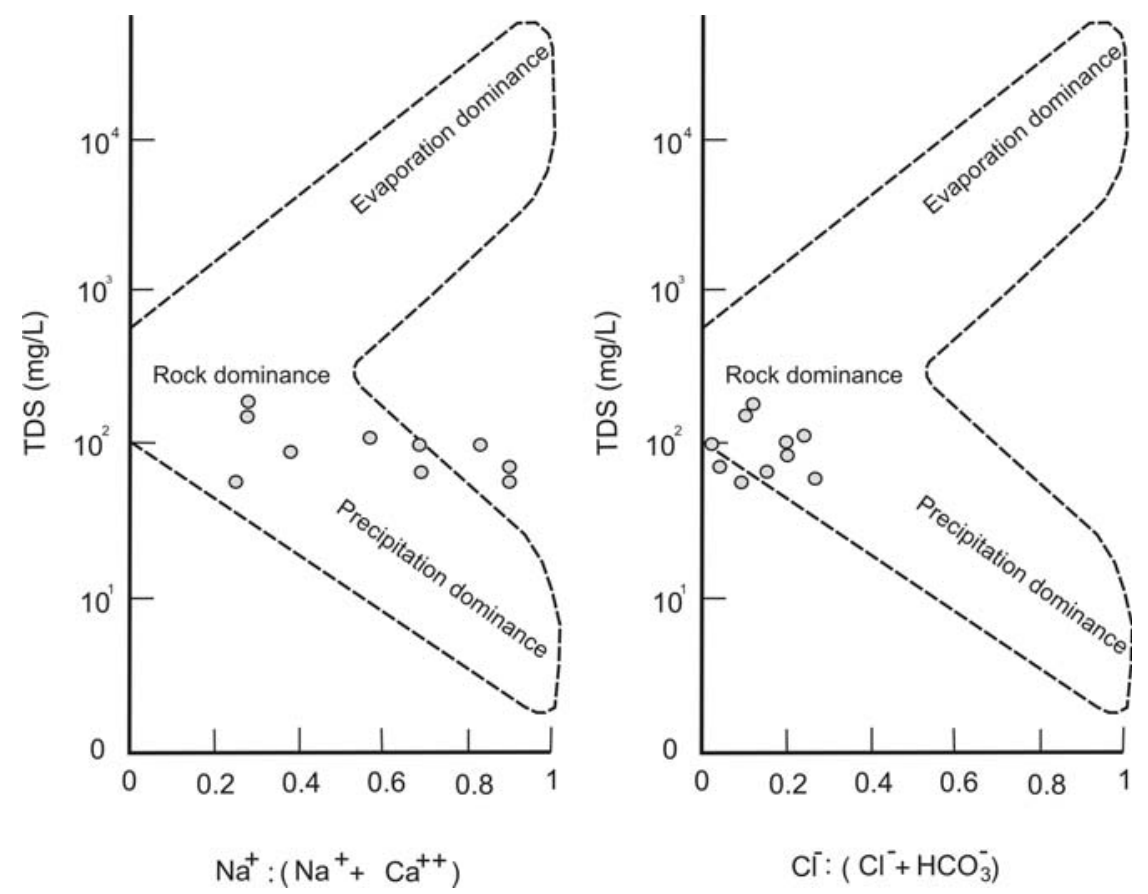

Figure 5. Mechanisms controlling the water chemistry $\mathrm{Na}^{+}:\left(\mathrm{Na}^{+}+\mathrm{Ca}^{2+}\right)$ versus $\mathrm{TDS}$ and $\mathrm{Cl}^{-}:\left(\mathrm{Cl}^{-}+\mathrm{HCO}_{3}^{-}\right)$versus TDS. Circles denote the chemical data of the water sampling stations.

Table 7. Distribution of groups.

\begin{tabular}{|c|c|c|c|c|c|c|c|}
\hline \multirow[b]{2}{*}{ Groups } & \multirow[b]{2}{*}{ Chemical variables } & \multicolumn{2}{|c|}{$\begin{array}{l}\text { First principal } \\
\text { component }\end{array}$} & \multicolumn{2}{|c|}{$\begin{array}{l}\text { Second principal } \\
\text { component }\end{array}$} & \multicolumn{2}{|c|}{$\begin{array}{l}\text { Third principal } \\
\text { component }\end{array}$} \\
\hline & & Positive & $\overline{\text { Negative }}$ & Positive & Negative & Positive & Negative \\
\hline A & $\mathrm{TH}, \mathrm{Mg}^{2+}$ & High & - & Low & Low $\left(\mathrm{Mg}^{2+}\right)$ & Low & Low $(\mathrm{TH})$ \\
\hline B & $\mathrm{Cl}^{-}, \mathrm{HCO}_{3}^{-}, \mathrm{K}^{+}$ & High & - & - & Low & - & Low \\
\hline $\mathrm{C}$ & $\mathrm{Na}^{+}$ & Moderate & - & - & Moderate & - & Low \\
\hline $\mathrm{D}$ & $\mathrm{SO}_{4}^{2-}$ & Low & - & - & High & Low & - \\
\hline $\mathrm{E}$ & $\begin{array}{l}\text { TDS, conductivity, } \\
\mathrm{Ca}^{2+}\end{array}$ & - & Low & High & - & Low & Low $\left(\mathrm{Ca}^{2+}\right)$ \\
\hline $\mathrm{F}$ & $\mathrm{pH}$ & - & Low & Low & - & Low & - \\
\hline G & $\mathrm{F}^{-}, \mathrm{SiO}_{2}$ & - & Low & Low & - & High & - \\
\hline $\mathrm{H}$ & $\mathrm{NO}_{3}^{-}$ & - & Low & - & Moderate & Moderate & - \\
\hline
\end{tabular}

Groups: low $=$ less than $( \pm)$ 0.500; moderate $=( \pm) 0.500-0.750 ;$ high $=$ grater than $( \pm) 0.750$.

the variations in the chemical composition of water, as also observed in the first, second, and third principal component loadings.

The first, second, and third principal components loading plots illustrated in table 5, are divided into eight groups (table 7), namely, A-H, on the basis of their relative positions. Various groups of water identified clearly indicate the variables which broadly distinguish the geogenic sources (groups A, B and C) from the anthropogenic ones (groups $\mathrm{D}$ and $\mathrm{E}$ ). It also infers that the variables in groups $\mathrm{A}, \mathrm{B}$, and $\mathrm{C}$ have high variability in the data set, in groups $\mathrm{D}$ and $\mathrm{E}$ variables have the second most influential function, and in groups $\mathrm{F}, \mathrm{G}$, and $\mathrm{H}$ variables have some influence on the variability in the dataset.

\section{Conclusions}

Water of the Chhoti Gandak River is hard at most places. The concentrations of $\mathrm{TH}, \mathrm{Mg}^{2+}$ exceed the safety limit prescribed for drinking at some of the stations and may cause physical disorders. At most of the stations however, water is of good quality for irrigation, and can be used for agricultural production. The scatter diagrams, ionic signatures, and mechanisms controlling the water 
chemistry diagrams indicate that the first principal components are controlled by gentle slope gradient, poor drainage conditions, long residence of water, high rate of weathering, ion exchange, heavy use of fertilizers, and domestic wastes. Variables in groups $\mathrm{A}, \mathrm{B}$, and $\mathrm{C}$ have high variability in the dataset, in groups $\mathrm{D}$, and $\mathrm{E}$ variables have the second most influential function, and in groups $\mathrm{F}$, $\mathrm{G}$, and $\mathrm{H}$ variables have some influence on the variability in the dataset. The groups broadly distinguished geogenic sources from the anthropogenic ones.

The present study suggests that the principal component analysis determines the assemblages of water quality, which are an indication of genetic processes and the origin of pollutants with respect to domestic and agricultural sectors. Analysis is useful for sustainable development through planning and for implementing remedial measures within time to mitigate the adverse effects of the poor quality of water on human health as well as on plant growth.

\section{Acknowledgements}

The financial assistance from Department of Science and Technology, Government of India, New Delhi is highly acknowledged (Project No SR/54/ES-21/Ganga Plain/ $\mathrm{P}_{3}$ ). We are also thankful to Prof. N L Chhabra, Head, Centre of Advanced Study in Geology, University of Lucknow, for providing working facilities and also for continuous encouragement. Our thanks are also due to Mr. Amit Awasthi.

\section{References}

American Public Health Association 1992 Standard methods for the examination of water and wastewater; 19th edn., Washington, D.C.

American Public Health Association 1998 Standard methods for the examination of water and wastewater; 20th edn., Washington, D.C.

Bartarya S K 1993 Hydrochemistry and rock weathering in a sub-tropical lesser Himalayan river basin in Kumaun, India; J. Hydrol. 146 149-174.

Bhardwaj V, Singh D S and Singh A K 2009 Hydrogeochemistry of ground water and anthopogenic control over dolomatization reaction in alluvial sediments of the Deoria district: Ganga Plain India; Environmental Earth Sciences 59(5) 1099-1109, doi: 10.1007/s12665009-0100-y.

Chettri M and Smith G D 1995 Nitrate pollution in ground water in selected districts of Nepal; Hydrogeol. J. 3 $71-76$.

Fetter C W 1990 Applied hydrogeology: New Delhi, India; CBS Publishers \& Distributors, 592 p.

Fisher R S and Mullican W F 1997 Hydrochemical evolution of sodium-sulfate and sodium-chloride ground water beneath the northern Chihuahuan Desert, Trans-Pecos, Texas, USA; Hydrogeol. J. 5 4-16.
Gibbs R J 1970 Mechanisms controlling world water chemistry; Science 17 1088-1090.

Gupta S K and Deshpande R D 2004 Water for India in 2050: First-order assessment of available options; Curr. Sci. 86 1216-1224.

Hall G E M 1998 Relative contamination levels observed in different types of bottles used to collect water samples; Explore 101 1-7.

Hem J D 1991 Study and interpretation of the chemical characteristics of natural water: Book 2254, 3rd edn., (Jodhpur, India: Scientific Publishers) 263 p.

Holden W S 1970 Water treatment and examination; (London: J \& Churchill Publishers) 513 p.

Indian Standard Institute 1983 Indian standard specification for drinking water; IS: 10500: India, Indian Standard Institute, $21 \mathrm{p}$.

Jacks G 1973 Chemistry of groundwater in a district in Southern India; J. Hydrol. 18 185-200.

Kaiser H F 1958 The varimax criterion for analytic rotation in factor analysis; Psychometrika 23 187-200.

Kumar S, Singh I B, Singh M and Singh D S 1995 Depositional pattern in upland surface of Central Ganga Plain near Lucknow; J. Geol. Soc. India 46 545-555.

Maiti T C 1982 The dangerous acid rain; Science Reporter $9360-366$.

Ozler H M 2003 Hydrochemistry and salt-water intrusion in the Van aquifer, east Turkey; Environ. Geol. 43 759-775.

Pascoe E H 1917 A manual of Geology of India and Burma; Govt. of India Publ., Delhi.

Sarin M M, Krishnaswamy S, Dilli K, Somayajulu B L K and Moore W S 1989 Major-ion chemistry of the GangaBrahmaputra river system: Weathering processes and fluxes to the Bay of Bengal; Geochim. Cosmochim. Acta 53 997-1009.

Satyanarayana M and Periakali P 2003 Geochemistry of ground water in ultrabasic peninsular gneissic rocks, Salem district, Tamil Nadu; J. Geol. Soc. India 62 63-73.

Scheytt T 1997 Seasonal variations in ground water chemistry near lake Belau, Schleswing-Holstein, northern Germany; Hydrogeol. J. 5 86-95.

Singh D S 2007 Flood Mitigation in Ganga Plain; In: Disaster Management in India (eds) Rai N and Singh A K, New Royal Book Company, Lucknow, pp 167-179.

Singh D S and Singh I B 2005 Facies architecture of the Gandak Megafan, Ganga Plain, India; Special Publication of the Palaeontological Society of India 2 125-140.

Singh D S, Awasthi A and Bhardwaj V 2009 Control of Tectonics and Climate on Chhoti Gandak River Basin, East Ganga Plain, India; Himalyan Geology 30(2) 147-154.

Singh I B 1996 Geological evolution of Ganga Plain - An Overview; J. Palaeontol. Soc. India 41 99-137.

Singh I B, Srivastava P, Shukla U, Sharma S, Sharma M, Singh D S and Rajagopalan G 1999 Upland interfluve (Doab) deposition: Alternative model to muddy overbank deposits; Facies 40 197-210.

Singh K P, Malik A, Mohan D and Sinha S 2004 Multivariate statistical techniques for the evaluation of spatial and temporal variations in water quality of Gomti River (India): A case study; Water Res. 38 3980-3992.

Stallard R F and Edmond J M 1983 Geochemistry of the Amazon River - The influence of the geology and weathering environment on the dissolved load; J. Geophys. Res. 88 9671-9688.

Subba Rao N and John Devadas D 2003 Fluoride incidence in ground water in a part of peninsular India; Environ. Geol. 45 243-251. 
Twort A C, Hoather R C and Law F M 1974 Water supply (London: Edward Arnold Publishing Ltd.) p 245.

Wang Y and Luo Tma Z 2001 Geostatistical and geochemical analysis of surface water leakage into ground water on a regional scale: A case study in the Liulin karst system, northwestern China; J. Hydrol. 246 223-234.
World Health Organization 1984 Guidelines for drinking water quality; Geneva, World Health Organization, $335 \mathrm{p}$.

Zhang J, Huang W W, Letolle R and Jusserand C 1995 Major element chemistry of the Huanghe (Yellow River), China - Weathering processes and chemical fluxes; J. Hydrol. 168 173-203.

MS received 15 April 2009; revised 18 September 2009; accepted 18 October 2009 